\title{
PEMANFAATAN SERAT IJUK PADA CAMPURAN PERKERASAN ASPHALT CONCRETE-WEARING COARSE (AC-WC) UNTUK MENGURANGI KERETAKAN AKIBAT GEMPA
}

\author{
Zikri Fathoni ${ }^{1}$, Frans Yanda Hafino ${ }^{2}$, Gita Satria Pratama ${ }^{3}$ \\ Gusri Rahayu ${ }^{4}$, Jeniko Yusri ${ }^{5}$ dan Purnawan ${ }^{6}$
}

\begin{abstract}
ABSTRAK
Perkerasan aspal merupakan jenis perkerasan yang paling banyak digunakan pada saat ini. Salah satu kelemahan dari perkerasan ini adalah kemudahan retak akibat pembebanan atau perubahan bentuk karena gaya geser. Wilayah Sumatera Barat merupakan salah satu wilayah yang terletak pada zona rawan gempa. Gempa tersebut sebagian mengakibatkan keretakan pada perkerasan jalan. Penelitian ini dilakukan untuk membuat perkerasan aspal yang tahan retak dengan menambahkan serat ijuk sebagai bahan penguat. Jenis perkerasan aspal yang digunakan dalam penelitian ini adalah Asphalt Concrete - Wearing Coarse (AC - WC). Pengujiannya menggunakan metoda Marshall. Sampel untuk pengujian terdiri dari sampel campuran perkerasan aspal biasa, sampel dengan variasi ukuran dan panjang sama, sampel dengan variasi panjang ijuk dengan kadar yang sama. Sampel dengan variasi kadar ijuk diambil 1\% - 5\% ijuk dengan panjang $2 \mathrm{~cm}$, didapat kadar optimum 3\%. Penelitian dengan melakukan variasi panjang ijuk 1, 3, 5, 7, 9 cm dengan kadar $3 \%$, didapatkan panjang optimum $3 \mathrm{~cm}$. Hasil penelitian ini menunjukkan bahwa penggunaan ijuk dapat meningkatkan stabilitas campuran perkerasan sebesar 27\%. Pada pengujian efek gempa pada sampel tanpa ijuk dan sampel yang diberi ijuk, komposisinya diambil dari hasil mix design sebelumnya yaitu $3 \%$ dari berat aspal dengan panjang $3 \mathrm{~cm}$. Pada uji efek gempa didapatkan data bahwa kedua sampel tidak mengalami keretakan setelah digetarkan dengan meja getar selama \pm 1 menit 50 detik.
\end{abstract}

Kata kunci : AC-WC, metoda marshall, serat ijuk, uji efek gempa

\section{PENDAHULUAN}

Jalan merupakan salah satu kebutuhan bagi masyarakat yaitu sebagai sarana penghubung dari suatu tempat ke tempat yang lain, baik itu jalan setapak ataupun yang telah diberikan perkerasan. Saat ini perkerasan yang sering digunakan adalah jenis perkerasan lentur. Kebutuhan manusia terhadap sarana transportasi menuntut manusia untuk terus memperbaharui tingkat pelayanan dari jalan tersebut. Manusia dituntut untuk mengatasi segala macam hal yang akan bisa menyebabkan kerusakan dari jalan. Kerusakan jalan bisa disebabkan oleh berbagai macam hal, yang bisa meyebabkan perkerasan itu sendiri bisa menjadi rusak salah satunya adalah gempa. Indonesia adalah daerah yang rawan terhadap bencana gempa, hal ini terkait dengan posisi Indonesia yang berada pada pertemuan empat lempeng tektonik, yaitu lempeng Indo-Australia, lempeng Eurasia,

\footnotetext{
${ }^{1}$ Mahasiswa Jurusan Teknik Sipil Fakultas Teknik Universitas Andalas, zikri_fath@yahoo.com

${ }^{2}$ Mahasiswa Jurusan Teknik Sipil Fakultas Teknik Universitas Andalas, fransyandahavino@yahoo.com

${ }^{3}$ Mahasiswa Jurusan Teknik Sipil Fakultas Teknik Universitas Andalas, slap_jack77@yahoo.com

${ }^{4}$ Mahasiswa Jurusan Teknik Sipil Fakultas Teknik Universitas Andalas, reinanera108@gmail.com

${ }^{5}$ Mahasiswa Jurusan Teknik Sipil Fakultas Teknik Universitas Andalas, j_nicks_name@yahoo.com

${ }^{6}$ Staf Pengajar Jurusan Teknik Sipil Fakultas Teknik Universitas Andalas, purnawan@ft.unand.ac.id
} 
lempeng Pasifik, dan lempeng Philipina (Delfebriyadi, 2010). Bencana gempa yang terjadi tidak hanya merusak struktur bangunan, tetapi juga merusak struktur perkerasan jalan, Kerusakan jalan yang disebabkan oleh gempa sumatera barat yang terjadi pada 30 September 2009. Total kerusakan jalan ada 258 jalan, rusak berat 167 jalan, rusak sedang 65, rusak ringan 26 (PUSDALOPS BNPB, 2009). Besarnya efek akibat gempa, maka diperlukan inovasi untuk mengurangi pengaruh gempa tersebut terhadap kerusakan jalan. Bahan yang digunakan untuk mengurangi kerusakan jalan tersebut adalah serat ijuk. Serat ijuk adalah salah satu bahan yang berasal dari pohon aren. Serat ijuk banyak dan mudah untuk diperoleh, karena bersumber dari pertanian. Ijuk mempunyai sifat awet dan tidak mudah busuk baik dalam keadaan terbuka (tahan terhadap cuaca) maupun tertanam dalam tanah.

\section{TUJUAN PENELITIAN}

Tujuan penelitian ini adalah :

1. Meneliti pengaruh penambahan serat ijuk pada campuran perkerasan aspal.

2. Menentukan persentase dan ukuran serat ijuk yang optimum dalam perencanaan perkerasan aspal untuk mengurangi keretakan akibat gempa.

\section{METODE PENELITIAN}

\subsection{Pengujian Bahan}

Pengujian bahan dilakukan untuk menentukan kelayakan dari suatu bahan yang akan digunakan sebagai bahan campuran perkerasan aspal. Bahan-bahan yang akan diuji, antara lain :

1. Agregat kasar

2. Agregat Halus

3. Filler

4. Aspal $60 / 70$

Jenis Pemeriksaan yang dilakukan untuk agregat :

1. Pemeriksaan berat jenis agregat Halus dan kasar (SNI 1969 : 2008)

2. Pemeriksaan ketahanan agregat terhadap mesin Los Angelas (SNI $2417: 2008$ )

3. Pemeriksaan berat isi (ASTM C-29-71)

4. Pemeriksaan kelekatan agregat terhadap aspal (SNI 03-2439-1991)

Jenis Pemeriksaan yang dilakukan untuk aspal

1. Pemeriksaan Berat jenis aspal (SNI 06-2441-1991)

2. Pemeriksaan Penetrasi aspal (SNI 06-2456-1991)

3. Pemeriksaan Kehilangan berat (SNI 06-2440-1991)

4. Pemeriksaan Daktilitas Aspal (SNI-06-2432-1991)

5. Pemeriksaan Titik Nyala dan Titik Bakar (SNI-06-2433-1991)

6. Pemeriksaan Titik Lembek (SNI 06-2434-1991)

\subsection{Mix Design}

Penelitian ini dilakukan dalam 3 tahapan mix design, pada setiap tahapan dilakukan mix design untuk penetapan kadar aspal optimum, mix design untuk penetapan kadar ijuk optimum, mix design untuk penetapan panjang ijuk optimum. Mix design dilakukan untuk menentukan proporsi gradasi agregat dan menentukan kadar aspal rencana. 
1. Pembagian Gradasi

Proses ini diawali dengan melakukan percobaan analisa saringan untuk mendapatkan pembagian gradasi dari agregat yang digunakan. Hasil gradasi yang diharapkan dari yaitu sesuai dengan amplop gradasi gabungan agregat untuk campuran AC - WC.

2. Penentukan Kadar Aspal Rencana

Dalam penetapan aspal teoritis, digunakan rumus 1.

$$
" \mathrm{~Pb}=0,035 .(\% \mathrm{CA})+0,045 .(\% \mathrm{FA})+0.18 .(\% \mathrm{FF})+\mathrm{K} "
$$

$$
\begin{aligned}
& \text { Keterangan: } \\
& \mathrm{Pb}=\text { Kadar aspal rencana awal } \\
& \mathrm{CA}=\text { Agregat kasar } \\
& \mathrm{FA}=\text { Agregat halus } \\
& \mathrm{FF}=\text { Bahan pengisi } \\
& \mathrm{K}=\text { Konstanta (untuk Laston } 0,5-1,0 \text { ) }
\end{aligned}
$$

3. Mix Design

a. Mix design untuk mendapatkan kadar aspal optimum : Agregat kasar + Agregat Halus + Filler + Aspal. Pencampuran yang digunakan adalah dengan menggunakan variasi aspal yaitu $\pm 0,5 \%$ kadar aspal rencana. Sampel sebanyak 15 buah masing-masingnya terdiri dari 5 variasi kadar aspal. Campuran diuji dengan alat Marshall, untuk mendapatkan nilai stabilitas, kelelehan, rongga dalam campuran, rongga dalam agregat, rongga terisi aspal, marshall quotient serta kadar aspal optimum.

b. Mix design untuk mendapatkan kadar ijuk optimum : Agregat kasar + Agregat Halus + Filler + Aspal + Variasi Kadar Ijuk. Pembeda dari mix design pertama, terletak pada variasi campuran dimana kadar aspal yang digunakan bernilai tetap, dengan melakukan variasi kadar ijuk yang digunakan sebagai bahan tambah pada campuran yaitu sebesar $2 \%$, $3 \%, 4 \%, 5 \%, 6 \%$ dari berat total aspal. Sampel dibuat sebanyak 15 buah dimana masingmasing variasinya dibuat sebanyak 3 buah. Pengujian dengan alat Marshall. Hasilnya kadar ijuk untuk digunakan pada mix design selanjutnya.

c. Mix design untuk mendapatkan panjang ijuk optimum : Agregat kasar + Agregat Halus + Filler + Aspal + Variasi Panjang Ijuk. Pembeda dari mix design pertama dan yang kedua, terletak pada variasi campuran dimana kadar aspal yang digunakan diambil dari mix design pertama dan kadar ijuk diambil dari mix design yang kedua, dengan melakukan variasi panjang ijuk yang digunakan pada campuran yaitu sebesar $1 \mathrm{~cm}, 3 \mathrm{~cm}, 5 \mathrm{~cm}, 7 \mathrm{~cm}, 9 \mathrm{~cm}$. sampel dibuat sebanyak 15 buah dimana masing-masing variasinya dibuat sebanyak 3 sampel. Campuran agregat yang telah selesai di cetak, kemudian akan dilakukan dilakukan pengujian dengan alat Marshall.

\subsection{Uji Efek Campuran Terhadap Gempa}

Kadar aspal, kadar ijuk dan panjang optimum ijuk yang didapatkan dari hasil mix design digunakan untuk membuat sampel untuk pengujian uji efek gempa. Sampel yang digunakan berukuran $(0.07 \mathrm{x}$ $0.07 \times 0,04) \mathrm{m} 3$. Sampel dibuat untuk mengidentifikasi efek dari uji gempa, pengujiannya dilakukan dengan alat uji gempa. 


\section{HASIL DAN PEMBAHASAN}

\subsection{Pemeriksaan Bahan}

Pemeriksaan bahan terdiri dari material agregat kasar dan agregat halus sedangkan untuk filler tidak dilakukan pemeriksaan karena digunakan semen portland tipe-I.

1. Agregat kasar. Pemeriksaan yang dilakukan untuk agregat kasar, dan diperoleh hasil Berat Jenis Bulk 2.51, Berat Jenis SSD 2.56, Berat Jenis Apparent 2.64, Penyerapan Air 1.91, Abrasi dengan mesin Los Angeles 23.9\%. Pengujian yang telah dilakukan seluruh didapatkan hasilnya masuk pada spesifikasi.

2. Agregat Halus. Pada pemeriksaan agregat halus, dan diperoleh hasil Berat Jenis Bulk 2.55, Berat Jenis SSD 2.62, Berat Jenis Apparent 2.74, Penyerapan Air 2.73\%. Pengujian yang telah dilakukan seluruh didapatkan hasilnya masuk pada spesifikasi.

3. Filler. Filler yang digunakan pada campuran perkerasan aspal Asphalt Concrete-Wearing Coarse adalah semen portland dengan tipe-I. Pemeriksaan terhadap filler yaitu berat jenis. Hasil pengujian digunakan data yang diambil dari referensi dimana berat jenis untuk semen portland tipe-I yaitu 3,15 (Putrowijoyo, 2006).

4. Aspal. Aspal yang digunakan pada campuran AC-WC yaitu aspal 60/70. Pemeriksaan aspal diantaranya Berat Jenis Aspal 1.04, Penetrasi Aspal 66.5, Daktilitas $150 \mathrm{~cm}$, Titik Nyala $252^{\circ} \mathrm{C}$, Titik Bakar $316^{\circ} \mathrm{C}$, Titik Lembek $55^{\circ} \mathrm{C}$, Kehilangan Berat $0.682 \%$.

\subsection{Perencanaan Gradasi Campuran}

Perencanaan gradasi campuran diawali dengan melakukan analisa saringan. Analisa saringan dilakukan pada agregat kasar, agregat halus, serta filler. Sehingga didapatkan penggabungan agregat dengan metoda analitis. $\mathrm{Pb}$ merupakan kadar aspal rencana, dibuat variasi sebanyak 5 buah, dimana masing-masing seperti yang terlihat pada Tabel 4.1.

Tabel 4.1 Perkiraan Kadar Aspal

\begin{tabular}{|l|l|l|l|l|}
\hline $\mathrm{Pb}-1.0$ & $\mathrm{~Pb}-0.5$ & $\mathrm{~Pb}$ & $\mathrm{~Pb}+0.5$ & $\mathrm{~Pb}+1.0$ \\
\hline $4.8 \%$ & $5.3 \%$ & $5.8 \%$ & $6.3 \%$ & $6.8 \%$ \\
\hline
\end{tabular}

Tabel 4.2 Rekapitulasi Hasil Mix design Design untuk Mendapatkan Kadar Aspal Optimum

\begin{tabular}{|l|l|l|l|l|l|l|}
\hline \multirow{2}{*}{ Karakteristik } & \multirow{6}{*}{ Syarat } & \multicolumn{5}{|c|}{ Cengujian Marshall 75 x tumbukan tanpa serat ijuk } \\
\cline { 3 - 7 } & & \multicolumn{5}{|c|}{ Kadar $(\%)$} \\
\cline { 3 - 7 } & & 4.8 & 5.3 & 5.8 & 6.3 & 6.8 \\
\hline Stabilitas (Kg) & $\geq 800$ & 658.2 & 614.6 & 622.6 & 742.2 & 794.2 \\
\hline Kelelehan (mm) & $\geq 3$ & 2.9 & 3.7 & 2.7 & 3.1 & 2.8 \\
\hline$\%$ VMA & $\geq 15$ & 18.6 & 19.1 & 19.3 & 18.8 & 18.4 \\
\hline$\%$ VFA & $\geq 65$ & 55.5 & 59.6 & 64.9 & 73.2 & 81.7 \\
\hline$\%$ VIM & $3-5$ & 8.3 & 7.7 & 6.7 & 5.1 & 3.4 \\
\hline MQ (kg/mm) & $\geq 250$ & 225.9 & 185.6 & 231.5 & 241.9 & 283.9 \\
\hline
\end{tabular}

\subsection{Mix Design}

Proses pencampuran agregat dilakukan dalam tiga tahapan, dimana masing-masing dilakukan secara bertahap.

1. Mix design untuk mendapatkan kadar aspal optimum

2. Mix design untuk mendapatkan kadar ijuk optimum

3. Mix design untuk mendapatkan panjang ijuk optimum 


\section{Mix design untuk Mendapatkan Kadar Aspal Optimum}

Pada proses pencampuran agregat yang pertama dilakukan proses pencampuran yang terdiri atas campuran agregat dan aspal. Kadar aspal rencana yang digunakan $(\mathrm{Pb})$ yaitu $5.8 \%$. Nilai dari hasil mix design ini merupakan karakteristik marshall yang dimasukkan pada semua grafik karakteristik Marshall, dimana nilai tersebut merupakan nilai rata-rata dari sampel untuk masing-masing kadar aspal rencana seperti pada Tabel 4.2 dan Gambar 4.1.
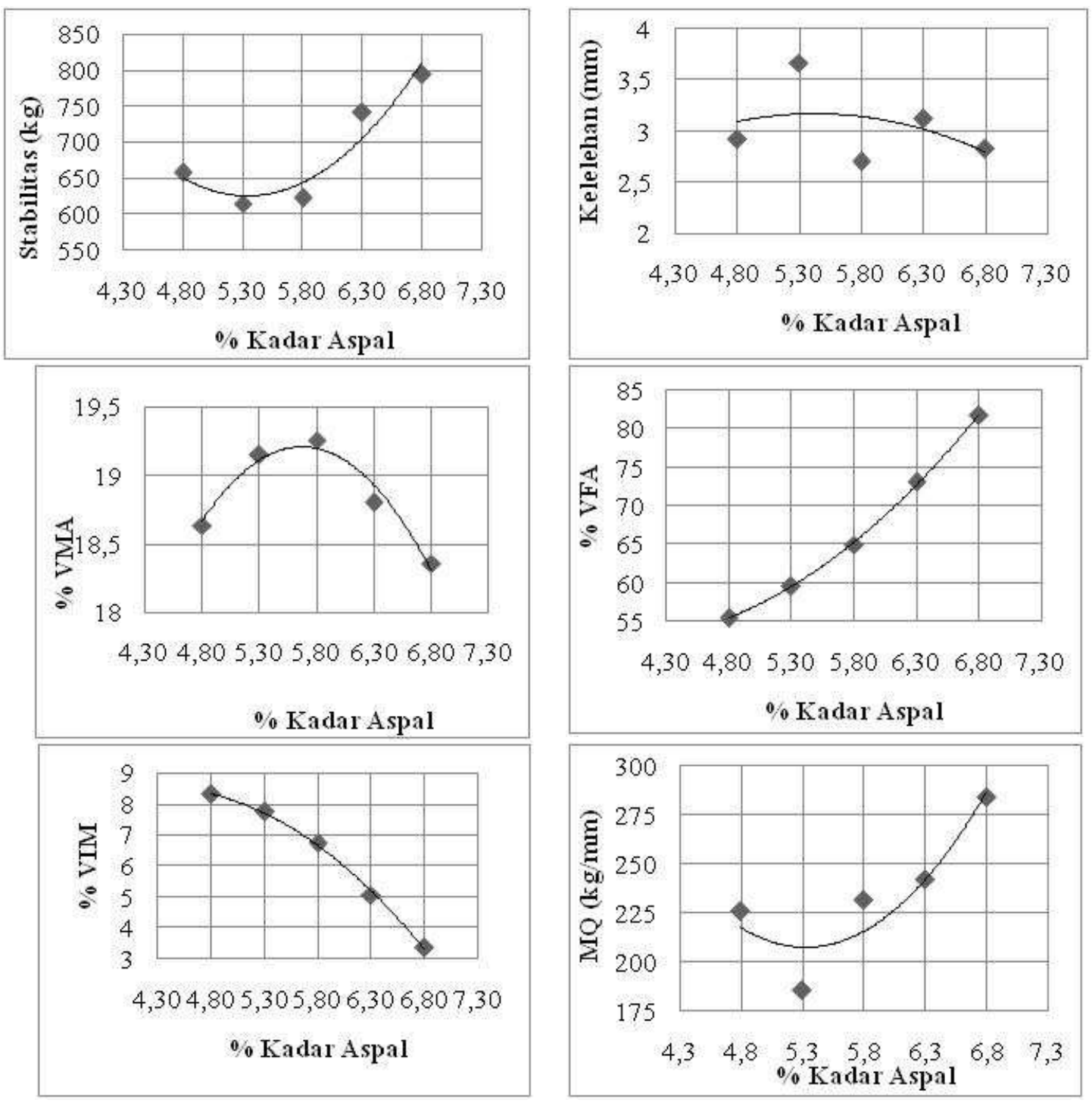

Gambar 4.1 Hasil Marshall Test Untuk Mendapatkan Kadar Aspal Optimum

Kadar aspal optimum yang sesuai dengan campuran perkerasan aspal yang digunakan adalah $6.3 \%$ yang diambil dari berat agregat.

\section{Mix Design untuk Mendapatkan Kadar Ijuk}

Pada mix design kedua dilakukan variasi terhadap kadar ijuk dengan panjang yang sama, dimana panjang yang digunakan yaitu $2 \mathrm{~cm}$ untuk mendapatkan. Sampel dibuat sebanyak 15 buah dengan 5 buah variasi kadar ijuk, yaitu 2\%, 3\%, 4\%, 5\% dan 6\% dengan kadar aspal yaitu 6.3\%. Nilai pada Tabel 4.3 merupakan karakteristik Marshall yang dimasukkan pada semua grafik karakteristik Marshall seperti Gambar 4.2. 
Tabel 4.3 Rekapitulasi Hasil Mix Design untuk Mendapatkan Kadar Ijuk Optimum

\begin{tabular}{|c|c|c|c|c|c|c|}
\hline \multirow{3}{*}{ Karakteristik } & \multicolumn{6}{|c|}{$\begin{array}{l}\text { Pengujian Marshall } 75 \times \text { tumbukan dengan variasi kadar serat ijuk yang } \\
\text { diambil dari berat aspal (ukuran } 2 \mathrm{~cm} \text { ) }\end{array}$} \\
\hline & Ijuk $(\%)$ & 2 & 3 & 4 & 5 & 6 \\
\hline & Aspal (\%) & 6.24 & 6.18 & 6.12 & 6.05 & 5.99 \\
\hline Stabilitas $(\mathrm{Kg})$ & $\geq 800$ & 865.3 & 945.8 & 868.1 & 888.4 & 864.9 \\
\hline Kelelehan (mm) & $\geq 3$ & 3.9 & 3.6 & 4.0 & 3.6 & 4.4 \\
\hline$\% \mathrm{VMA}$ & $\geq 15$ & 21.5 & 20.7 & 20.5 & 21.3 & 22.3 \\
\hline$\%$ VFA & $\geq 65$ & 61.5 & 63.5 & 63.8 & 60.2 & 56.0 \\
\hline$\%$ VIM & $3-5$ & 8.3 & 7.5 & 7.5 & 8.5 & 9.8 \\
\hline MQ (kg/mm) & $\geq 250$ & 224.1 & 261.1 & 215.5 & 256.5 & 198.5 \\
\hline
\end{tabular}
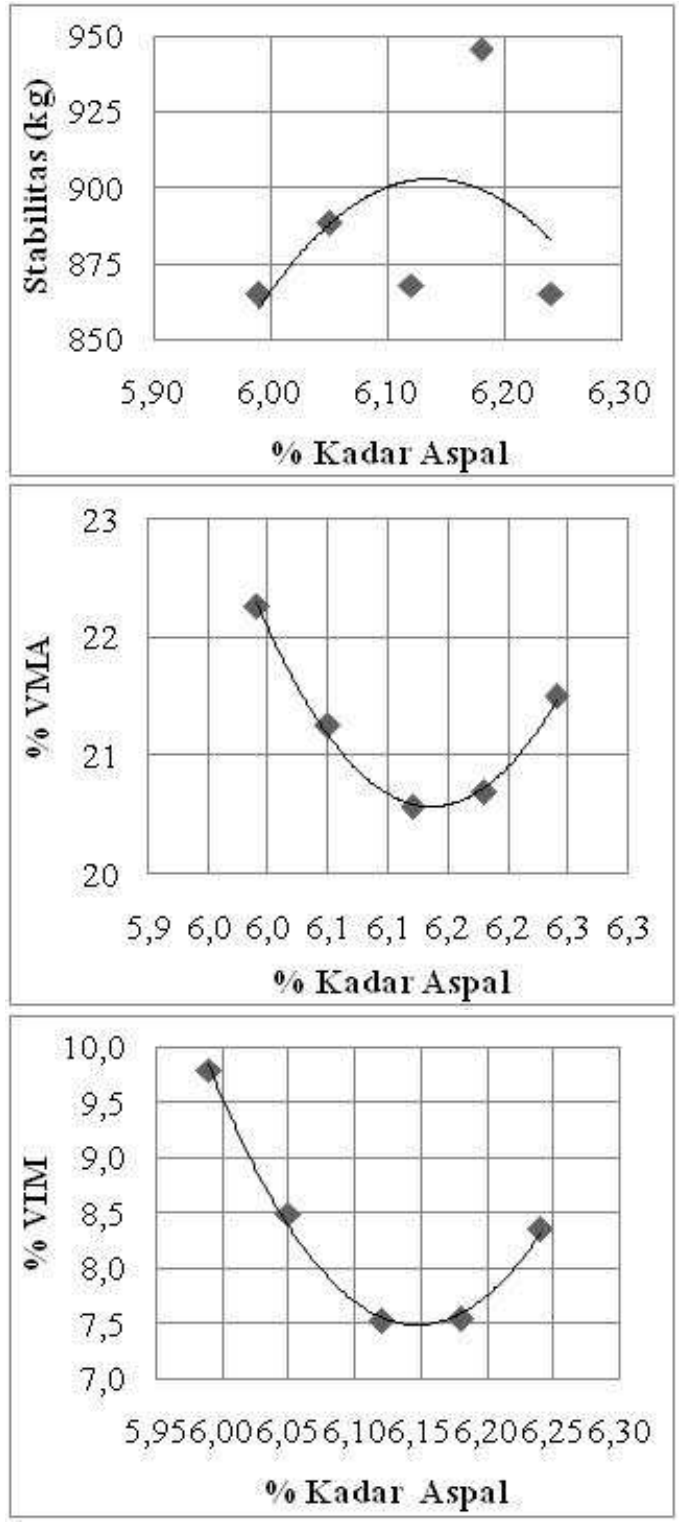
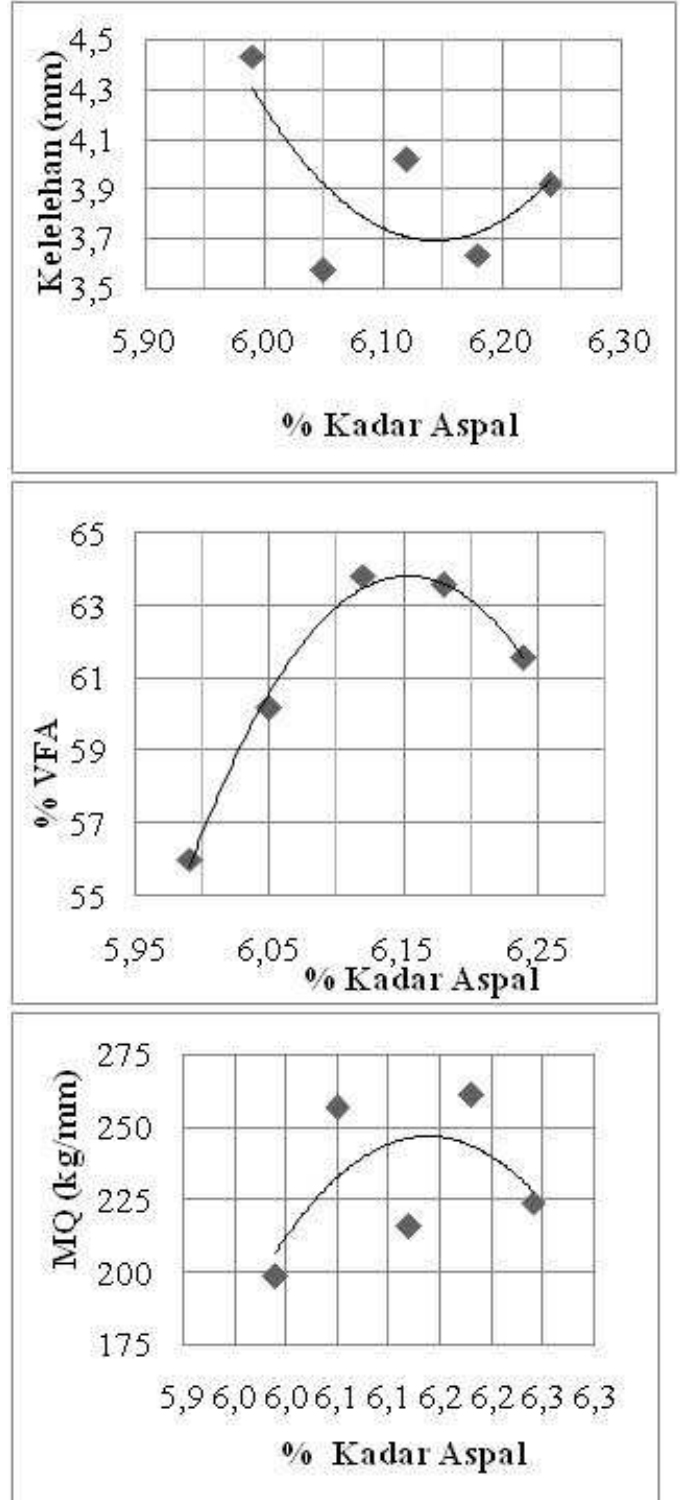

Gambar 4.2 Karakteristik Marshall hasil Mix Design untuk Mendapatkan Kadar Ijuk Optimum 
Tabel 4.4 Rekapitulasi Hasil Mix Design untuk Mendapatkan Panjang Ijuk

\begin{tabular}{|l|l|l|l|l|l|l|}
\hline \multirow{3}{*}{ Karakteristik } & \multicolumn{6}{l|}{ Pengujian Marshall 75 x tumbukan dengan variasi panjang serat ijuk (kadar ijuk $3 \%$ ) } \\
\cline { 2 - 7 } & Ijuk (cm) & 1 & 3 & 5 & 7 & 9 \\
\cline { 2 - 7 } & Aspal (\%) & 6.18 & 6.18 & 6.18 & 6.18 & 6.18 \\
\cline { 2 - 7 } & Syarat & & & & & \\
\hline Stabilitas $(\mathrm{Kg})$ & $\geq 800$ & 751.8 & 821.4 & 783.6 & 783.4 & 701.7 \\
\hline Kelelehan & $\geq 3$ & 2.4 & 2.9 & 2.8 & 2.5 & 2.1 \\
\hline$\%$ VMA & $\geq 15$ & 19.3 & 19.8 & 21.0 & 19.5 & 20.3 \\
\hline$\%$ VFA & $\geq 65$ & 69.5 & 67.0 & 64.0 & 68.5 & 65.1 \\
\hline$\%$ VIM & $3-5$ & 5.8 & 6.5 & 7.9 & 6.2 & 7.1 \\
\hline MQ & $\geq 250$ & 318.6 & 290.0 & 282.6 & 324.3 & 350.6 \\
\hline
\end{tabular}
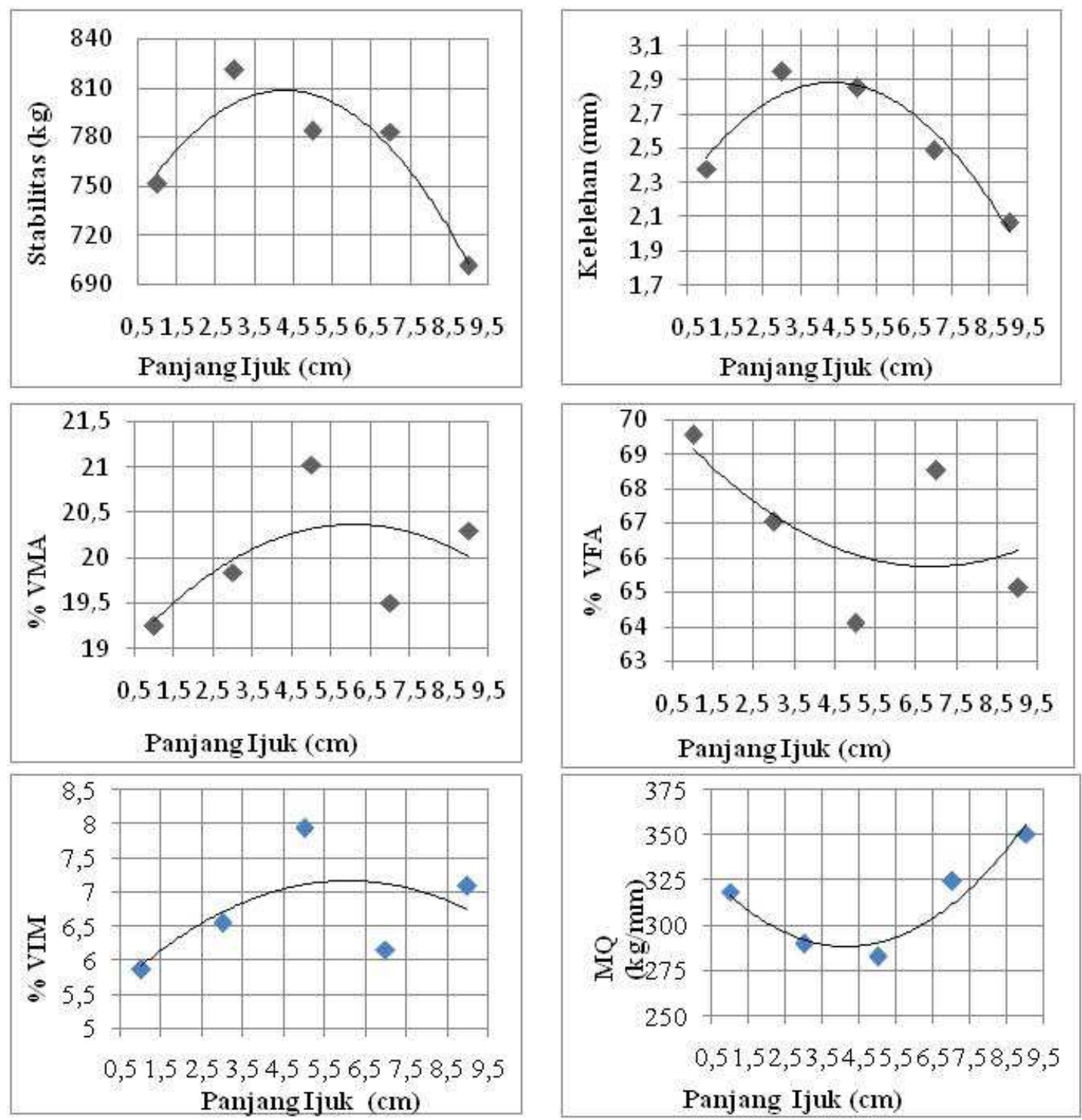

Gambar 4.3 Karakteristik Marshall hasil Mix Design untuk Mendapatkan Kadar Ijuk Optimum

\section{Mix Design untuk Mendapatkan Panjang Ijuk Optimum}

Pada tahapan ini, dilakukan mix design campuran dengan melakukan variasi terhadap panjang ijuk, sedangkan untuk kadar aspal dan kadar ijuk diambil dari hasil mix design sebelumnya. Variasi panjang ijuk yang digunakan yaitu, $1 \mathrm{~cm}, 3 \mathrm{~cm}, 5 \mathrm{~cm}, 7 \mathrm{~cm}, 9 \mathrm{~cm}$. Sampel dibuat sebanyak 15 masing- 
masingnya dibuat sebanyak 3 buah. Pengujian selanjutnya yaitu dengan melakukan pengujian dengan alat Marshall. Nilai pada Tabel 4.4 merupakan nilai rata-rata karakteristik Marshall dari masing-masing sampel untuk masing-masing variasi panjang ijuk seperti pada Gambar 4.3.

Pada tahapan mix design ini, penentuan panjang ijuk optimum ditentukan dari titik tengah karakteristik Marshall. Pengaruh variasi panjang ijuk dengan kadar yang sama pada semua campuran yaitu 3\% memberi pengaruh yang besar pada campuran aspal. Titik tengah dari karakteristik yang didasarkan pada syarat untuk jenis campuran Laston menunjukkan nilai panjang ijuk optimum untuk campuran perkerasan aspal didapatkan nilai optimum yaitu $4.25 \mathrm{~cm}$. Pengaruh penggunaan serat ijuk pada campuran perkerasan aspal terlihat pada nilai karakteristik Mashall yang ditampilkan pada Gambar 4.4.

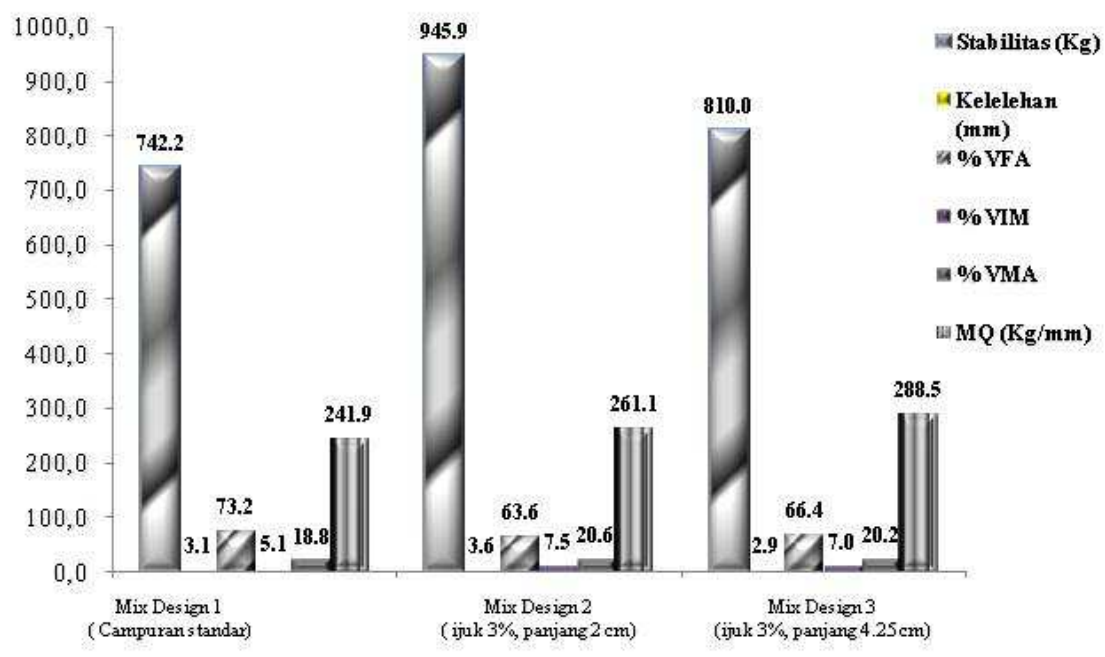

Gambar 4.4 Perbandingan Hasil Mix Design 1, 2 dan 3

Dari hasil mix design 1, 2 dan 3 diperoleh hasil bahwa penggunakan ijuk pada campuran aspal beton (Laston) jenis AC-WC mempengaruhi karakteristik nilai Marshall dari campuran. Penggunaan serat ijuk yang optimal dapat meningkatkan nilai dari karakteristik Marshall, sebaliknya bila ijuk digunakan dalam jumlah yang banyak juga akan menurunkan kekuatan dari campuran Laston. Pengaruh yang terjadi akibat penggunaan ijuk pada campuran dibandingkan dengan sampel tanpa penggunaan ijuk ditunjukkan pada Gambar 4.4. Pada Gambar 4.4 terlihat bahwa hasil pengujian yang menghasilkan kekuatan optimum terjadi jika kadar ijuk optimum yaitu $3 \%$ dari berat aspal dan untuk panjang ijuk optimum berkisar antara $2 \mathrm{~cm}-4.25 \mathrm{~cm}$.

\subsection{Uji Efek Gempa}

Setelah mendapatkan kadar ijuk beserta panjang ijuk optimum dari mix design awal. Selanjutnya dilakukan pengujian efek gempa terhadap campuran tanpa penggunaan ijuk dan campuran dengan penggunaan ijuk. Komposisi dari kadar ijuk beserta panjang ijuk optimum yang telah didapatkan yaitu kadar ijuk sebanyak 3\% dari berat aspal dengan panjang yang digunakan yaitu $3 \mathrm{~cm}$, sedangkan untuk berat aspal sendiri $6.18 \%$ yang diambil dari berat agregat. Sampel dicetak sebanyak 2 buah dengan ukuran $70 \times 70 \mathrm{~cm}$ dengan ketebalan $4 \mathrm{~cm}$ dan sampel dicetak dengan variasi yang berbeda. Gradasi campuran yang digunakan merupakan gradasi yang telah didapatkan dari perencanaan gradasi agregat merupakan gradasi agregat yang telah didapatkan pada perencanaan gradasi awal. Pengujian dilakukan secara bersamaan, dimana kedua sampel diletakkan bersandingan. Proses pengujian dilakukan dengan menggetarkan secara horizontal sampel di atas meja getar hingga waktu tertentu. Dai hasil pengujian, setelah sampel digetarkan selama \pm 1 menit 
50 detik, didapatkan hasil bahwa kedua sampel masih seperti semula dan belum terlihat retak setelah digetarkan, hal ini terjadi karena alat yang digunakan tidak mampu menampilkan pergeseran lapisan secara horizontal akibat gempa.

\section{KESIMPULAN}

Dari hasil penelitian yang telah dilakukan diperoleh, penggunaan serat ijuk yang optimal dapat meningkatkan kemampuan campuran perkerasan aspal, diantaranya nilai stabilitas campuran perkerasan aspal bisa meningkat hingga $27 \%$. Serat ijuk yang digunakan untuk menggantikan berat aspal adalah sebesar 3\% dengan panjang optimum ijuk berkisar $2-4.25 \mathrm{~cm}$.

\section{UCAPAN TERIMAKASIH}

Terimakasih kepada Pekan Kreativitas Mahasiswa (PKM) Tahun 2012, yang telah mendanai penelitian ini serta kepada seluruh rekan-rekan mahasiswa JurusanTeknik Sipil Fakultas Teknik Universitas Andalas, yang telah membantu hingga penelitian ini selesai.

\section{DAFTAR KEPUSTAKAAN}

Badan Meteorologi, Klimatologi dan Geofisika (2010). Gempa Bumi. http://www.bmkg.go.id/BMKG_Pusat/ Geofisika/gempabumi.bmkg (diakses 23 September 2011 )

Delfebriadi. (2010). Rekayasa Gempa. Universitas Andalas.

Departemen Pekerjaan Umum. (2007). Spesifikasi Teknis Jalan dan Jembatan. Balitbang.

Departemen Pemukiman dan Prasarana Wilayah. 2004. Manual : Pekerjaan Campuran Beraspal Panas.

Direktorat Jendral Bina Marga. (2010). Spesifikasi Campuran.

PUSDALOPS BNPB. (2009). Peta Jumlah Kerusakan Fasilitas UmumAkibat Gempa Di Provinsi Sumatera Barat.

Putrowijoto, R. (2006).Kajian laboratorium sifat marshall dan Durabilitas Asphalt Concrete - Wearing Course (AC-WC) dengan Membandingkan penggunaan antara semen portland dan abu batu sebagai Filler. Semarang: Universitas Diponegoro.

Sukirman, S. (2003). Beton Aspal Campuran Panas. Bandung : Nova. 